\title{
The Representation of Cina on Indonesian Twitter
}

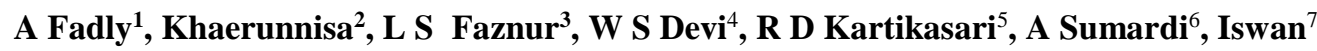 \\ $\left\{{ }^{1}\right.$ ahmad.fadly@umj.ac.id, ${ }^{2}$ khaerunnisa@umj.ac.id, ${ }^{3}$ lutfi.syauki@umj.ac.id, ${ }^{4}$ wikasoviana@umj.ac.id, \\ ${ }^{5}$ r.dewikartikasari@umj.ac.id \} \\ 1,2,3,4,5,6,7 Universitas Muhammadiyah Jakarta, Indonesia
}

\begin{abstract}
Ahead of the 2019 presidential and vice presidential election contestation, Chinese issues arose in Twitter and becomes discourse on it. Debate on this issue is particularly related to "Is it proper to 'get a place' and is compatible with Indonesian identity?" However, pragmatically the disagreement is not limited to dialectics that occurs in society, but is often associated with efforts to support or reject certain presidential candidates. Thus, representation on social media can be a "gateway" for acts of violence. For this reason, the representation needs to be revealed by using Critical Discourse Analysis (CDA) and operating Appraisal System (AS). The data were collected from tweets and responds between September 23, 2018 until April 13, 2019. Based on the data revealed that term Cina was not used appropriately. It is sometimes used to generalize between China as a state and Chinese as a race and is used to control netizens as well.
\end{abstract}

Keywords: Representation, Critical Discourse Analysis, Appraisal System

\section{INTRODUCTION}

Ahead of the 2019 presidential and vice presidential election contestation, various issues arose in the online media. The Chinese issue colors the news and media opinion so that it becomes a discourse on social media too. Debate on this issue is particularly related to "Is it proper to 'get a place' and is compatible with Indonesian identity?" However, pragmatically the disagreement is not limited to dialectics that occurs in society, but is often associated with efforts to support or reject certain presidential candidates. The dispute was intensified in the political year (2019) because many Chinese issues were attached to supporters of the 2019 Presidential and Vice-Presidential Candidates (PVPC) elections. Some called for a serious threat from China to the Unitary State of the Republic of Indonesia (NKRI) if a pair of PVPC candidate selected. And vice versa, some others warned of a big threat from groups other than China if another candidate won the election. Therefore, everything that "smells" of China is very vulnerable to talk about.

The increasingly widespread Chinese discourse is inseparable from the events that preceded it. In 2015 there was a case of blasphemy involving the former Governor of DKI Jakarta, Basuki Tjahaja Purnama (BTP) [1], who came from the Chinese ethnic. As a result, a group of people initiated the 212 Action at the Jakarta Monas which was considered beneficial to extremist or Radical Islamic groups [2]. BTP - which in the 2011 DKI Governor Election is paired with Joko Widodo - is supported and promoted by the Indonesian Democratic Party of Struggle (PDIP). The party also supported and promoted Joko Widodo as the 2019 Presidential Candidate. Therefore, the initiator of the 212 Act continued other actions (actions 411 and reunion 212) 
even though the target had changed [3], [4]. When the 212 Act was first intended for BTP to be imprisoned, while the 411 action and 212 reunion targeted a change of president in 2019.

After the BTP was criminalized, social cases that began with statements on social media emerged and increased. Based on data from the Southeast Asia Freedom of Expression Network (SAFEnet), cases of persecution increased after the conviction of BTP under the blasphemy law. The phenomenon, called The Ahok Effect, occurs on accounts deemed insulting to scholars or religion on social media [5]. Many of the acts of persecution (more than 100 citizens in Indonesia) were preceded by the act of doxing ('illegal actions in the form of searching and distributing personal data with malicious intentions') carried out by certain groups and are correlated with a number of mass organizations [6]. In their action, the group carried out four stages, namely (1) an invitation to collect targets, target data collection, to be widely distributed; (2) invitation to hunt, coordinate hunting; (3) forcing apologies, documenting them, and making them available on social media; and (4) taken to the police station, requesting detention. Thus, representation on social media can be a "gateway" for acts of violence. For this reason, the representation needs to be revealed.

In the 2019 Presidential Election there were only two registered candidates for Presidential and Vice Presidential Candidates. The limited candidate was caused by the minimum threshold of seats in parliament owned by political parties [7]. Only political parties that have more than $20 \%$ of the votes in parliament may and are entitled to submit a candidate. Meanwhile, the political parties that met the minimum threshold were only the PDIP and the Gerindra Party. As a result, other parties must form a coalition with one of the two parties to be able to carry the presidential candidate.

The limited number of candidates and vice presidential candidates led to sharp polarity among his supporters. In effect, supporters of the two camps identified themselves (self) by distinguishing them from other supporters (the others) in binary opposition. Therefore, it is not uncommon to display crossing issues such as left vs. right, extremists vs. communists, etc. on social media, especially Twitter.

Twitter is a social media that is characterized by the intensity of interaction between citizens. The media features comments and responses columns so that what is tweeted can be responded to and responded to by other citizens. In 2019, which is an election year, Twitter is characterized by intensive interaction between citizens around the issue of Presidential and Vice President, particularly on China issue.

In its use - especially on social media-, the language can construct and at the same time be constructed. When people try to give meaning to a phenomenon or use it as a strategy of power, they are constructing language. The construction can create reality [8]. Likewise, when citizens tweet (tweet) a Chinese phenomenon basically occurs construction of the issue. If the construction is negative, it will build an image that the two issues are negative as well. Thus, language is not a neutral phenomenon, but is always related to the development of awareness of a problem or issue. Therefore, through CDA, Chinese construction will be revealed. Conversely, language is constructed because it is not only constructed by its syntactic elements, but also its semiotic sign.

Several researches operated CDA in various data [2], [9], [10]. However, the lack of CDA research twitter-based has been taking place. That approach, also called the critical discourse studies, examines ways of abusing social power, domination, and injustice that are raised through texts and conversations in the socio-political context [8], [11], [12]. Because, the discourse in society is not merely describing reality, but also as a social practice. With that function, discourse does not always represent reality clearly. Therefore, CDA tries to uncover the "unclearness" [9]. As such, CDA is distinguished from discourse analysis. Discourse 
analysis produces a description, while CDA is not limited to describing but also social criticism, even sometimes there is intervention from researchers on injustice, domination, exploitation, and power relations [13].

Technically, CDA is a systematic impact of the choice of certain language elements or grammatical construction in a text [14]. Thus, the main concept in CDA as discourse, a series of complex communicative events and reflected through written and oral [15]. Therefore, CDA can be applied by examining linguistic features, such as categorizing themes based on collocation [16], the use of pronouns in political rhetoric [17], and systemic functional linguistics [9], [18]. However, those researches have limitations. Collocation may uncover the theme of a discourse, but it does not ensure all clauses to be revealed. The use of pronouns probably can show the allignment of speaker in a speech, but it only distinguishs ingropness and outgroupness. Systemic functional linguistics that classify three metafunctions: ideasional, interpersonal and textual [9], [19], [20] may can depict what underpin in a discourse, but to analyse interpersonal meaning needs to be sharpened because it only accommodate mood an residue. The theory that interpersonal meaning is appraisal system [21]. It can analyse the relation between speaker (or writer) and listener (or reader) deeper. In the theory introduced engagement, attitude and graduation [22]. Engagement refers to a clause that represents interpersonal meaning that could be simpe clause, complex clause, imperative and interrogative structure [22].

\section{RESEARCH METHOD}

This qualitative research bases CDA to reveal representation China on Indonesian Twitter. It operates AS to get interpersonal meaning particularly in connection with participant's relation: writer and reader through Twitter. The data were collected from Twitter from September 23, 2018 until April 13, 2019 due to campaign period. These researchers sorted the data manually because advanced feature in Twitter could not recognize and differentiate which one is Malaysian language and Indonesian language. They limited and chose Indonesian tweets only as data. The data were analyzed by operating appraisal system (AS) as offered by White [22] that classify it into three kinds: engagement, attitude and graduation.

\section{RESULTS AND DISCUSSION}

This research found that based on the data all tweets were categorized and analyzed into three metafunctions: engagement, attitude and graduation. This paper found 86 tweets regarding representation of China even these researchers excluded the profile of Twitter account to ensure his/her privacy. Based on engagement level, several tweets represent China as public enemy, even if it refers to descent (race) or state.

a. Engagement

Interpersonal meaning depicted from engagement that devided propositions into two characteristics: informative and interactional. Besides, the clause could be classified into two kinds: mono-gloss and hetero-gloss which the first one means that the clause is simple statement, does not contain modus and modality while the latter one means the clause contains a shift in meaning. Both mono-gloss and hetero-gloss affect interpersonal relation between writer (tweet maker) and its reader. In addition, hetero-gloss was differentiated into intra-vocalise and extra-vocalise which previos one means that an utterance produced by summarizing or modifying another text so that it feels like the writer's own. On the contrary, extra-vocalise means taking or quoting from another text directly. 
According to data, there were tweets used interactional proposition such imperative form below.

"Terus nanti yang ngisi loker di bank orang cina... Terus dia bilang 'cina tros yg dapat kerja! Kami jadi budak!"

That tweet seems informative proposition, but it implicitly means emotional relation from writer to reader on China issue. The writer expressed his/her emotional feel about China. The data is also pictured that the writer utilized hetero-gloss, especially intra-vocalise that he wrote as if it was quoted from another text but actually with his/her own style of utterance. Another tweets were categorized as combining intra-vocalise and extra-vocalise heterogloss. The combination could be depicted as one of them below.

"Breaking news! Terbukti, ternyata kata dirjen imigrasi ronny sompie di tvOne, TKA cina sudah masuk sekitar 1.3000 .000 orang (2016) itu belum dihitung sampai di tahun 2019. Jelas sekali setelah Jokowi bebaskan visa RI untuk cina RRC \& kerjasama MoU investasi."

The writer of the tweet used another text to be quoted (kata dirjen imigrasi ronny sompie di tvOne, TKA cina sudah masuk sekitar 1.3000 .000 orang (2016) itu belum dihitung sampai di tahun 2019) to support his/her opinion or attitude (Jelas sekali setelah Jokowi bebaskan visa RI untuk cina RRC \& kerjasama MoU investasi).

Several tweets represent unharmonious relation between writer and reader regarding to cina in connection with presidential election. Those are showed, for instance, on tweet below.

“Tak penting jumla yg mau kau hitung berapapun@Dennysiregar7 bisa gak kau atw Jokowi sekalipun menghadirkan rakyat sebanyak itu tanpa diberi uang, tanpa nasbung, tanpa jemputan bis, tanpa preman, tanpa apparat ASN lurah kades Bupati gubernur. Atw kau mo pi ke cina atau korut?"

That tweet represents that the writer ignored calculation made by @Dennysiregar7 and challenged to create such event (to mobilize people selfless). Another data depicted dialectics between positive and negative representation on China. One tweet was published in April 6, 2019 and one another was in April, 2019. The first one can be seen below.

"Jakarta rusuh Suharto mundur Fitnah Pemerkosaan Massal Perempuan etnis Cina disebarluaskan Pelarian modal dan perampokan BLBI ratusan triliun oleh 25 bankir cina tertutupi Tionghoa seolah2 menjadi korban terbesar."

Meanwhile, the latter data shown below.

"Pada peristiwa Mei 1998, lebih dari 150 orang perempuan etnis Cina mengalami perkosaan dan pelecehan seksual, demikian catatan sebuah tim relawan kasus Mei 1998, dan kasusnya tak juga kunjung terungkap, hingga kini, 20 tahun kemudian, dan tak ada."

The last two data opposited one another. The first represents that many issue on China that were not true and only narrative strategy used to get legitimation from society. While the latter one represents the opposition.

\section{b. Attitude}

Attitude refers to evaluative writer to lead opinion that is represented from its phrase, particularly by using adjective and adverb attributes. That attitude is distinguished into three dimensions: appreciation, judgement and affect. Appreciation is used to respond an object, process and product that could be negatively or positively depends on the meaning 
posed. Meanwhile, judgement means evaluative stance toward someone's behavior that colud be positively or negatively, depending on the norm referred. Affect means emotional response that marked by mental verbs as adore, love, hate, etc.

According to data, there were tweets that represent attitude of the writer to cina as follows.

"Kesalahan terbesar ADP adalah tidak bermata ngantuk kayak Royson Jiordano, anak cina penghina presiden."

That tweet framed that the writer compared ADP to Chineman that has priviledge due to his "Chinessness". That data encourages how China placed as an object that must be avoided because of special treatment they get from authority.

\section{c. Graduation}

Graduation is shift-meaning scale that consists of force and focus. Force means giving special pressure by phrasing, for example, excellent service. Meanwhile, focus means a pressure that could be up or down and has gradation in meaning as a bit hard (that colud be differentiated from easy, very easy, so hard, etc.). From the data depicted that cina was represented as superior nation especially in medicine sector by using superlative degree (paling jago).

"Dokter paling jago untuk neurorestorasi itu ya dari Cina... Bapak yang lagi terbujur sakit itu butuh ahli neurorestorasi segera biar bisa tampil gagah lagi di podium. Tapi abis itu kalian ummat2nya puasa dulu maki2 cina... biar barokah."

The tweet contains the highest scale of degree so that it indicated that there is still resistance to encounter negative frame in the discourse [23].

\section{CONCLUSIONS}

Cina that could be refers to a race and a state (The People's Republic of China) was represented on Twitter in various ways. Based on AS perspective, cina was pictured as superordinate term and used confusingly. Cina, either as a race or a state was represented as public enemy. By using extra-vocalise and intra-vocalise, China was represented negatively to control netizens' mind. However, there were resistance to defend and position the term properly.

\section{REFERENCES}

[1] A. Mahkamah, "Putusan Mahkamah Agung Republik Indonesia Nomor 1537/Pid.B/2016/PN.Jkt.Utr,” Jakarta, 2016.

[2] M. S. Al Fajri, "the Representation of a Blasphemy Protest in Jakarta in Local and International Press,” Indones. J. Appl. Linguist., vol. 7, no. 3, p. 705, 2018.

[3] N. K. Bhimo, "Manuver Politik di Balik Aksi Demo 4 November," Tirto.id, 2016. [Online]. Available: https://tirto.id/manuver-politik-di-balik-aksi-demo-4-novemberb1NX.

[4] SAH, "Reuni Aksi 212 Dinilai untuk Kepentingan Politik," CNN Indonesia, 2018. [Online]. Available: https://www.cnnindonesia.com/nasional/20181121204654-32348254/reuni-aksi-212-dinilai-untuk-kepentingan-politik.

[5] D. Juniarto, "Hat i-Hati Terciduk Kasus Persekusi," 2017.

[6] S. Voice, "Memindai Aktivitas MCA dalam Kontestasi Sosial Politik di Indonesia," 
2018.

[7] U.-U. Pemilu, "Undang-Undang Republik Indonesia Nomor 7 Tahun 2017 tentang Pemilihan Umum," 2017.

[8] Haryatmoko, Critical Discourse Analysis (Analisis Wacana Kritis): Landasan Teori, Metodologi dan Penerapan. Jakarta: PT Raja Grafindo Persada, 2016.

[9] U. Yuwono, "Ideologies underpinning the Indonesian National Qualification Framework (IQF) for higher education website text," Indones. J. Appl. Linguist., vol. 8, no. 3, p. 668, 2019.

[10] Z. Sakhiyya, "Negotiating social identity through questions in casual conversations: A critical discourse analysis," Indones. J. Appl. Linguist., vol. 6, no. 2, pp. 311-318, 2017.

[11] A. M. Irawan, “They are not Muslims': A critical discourse analysis of the Ahmadiyya sect issue in Indonesia," Discourse Soc., vol. 28, no. 2, pp. 162-181, 2017.

[12] T. Van Dijk A, The Handbook of Discourse Analysis. Massachusetts: Blackwell Publisher Inc, 2008.

[13] B. Johnson, Discourse Analysis. Massachusetts: Blackwell Publisher Inc., 2002.

[14] S. Mills, M. Foucault, S. Mills, C. Studies, and R. C. Thinkers, Discourse. London: Routledge, 2004.

[15] T. van Leeuwen, Discourse and Practice: New Tool s for Critical Discourse Analysis. New York: Oxford University Press, 2008.

[16] P. Pérez-Paredes, P. A. Jiménez, and P. S. Hernández, "Constructing immigrants in UK legislation and Administration informative texts: A corpus-driven study (2007-2011)," Discourse Soc., vol. 28, no. 1, pp. 81-103, 2017.

[17] J. Riihimäki, "At the heart and in the margins: Discursive construction of British national identity in relation to the EU in British parliamentary debates from 1973 to 2015," Discourse Soc., 2019.

[18] G. Turner, S. Mills, I. van der Bom, L. Coffey-Glover, L. L. Paterson, and L. Jones, "Opposition as victimhood in newspaper debates about same-sex marriage," Discourse Soc., vol. 29, no. 2, pp. 180-197, 2018.

[19] T. Bloor and M. Bloor, "The Functional Analysis of English: A Hallidayan Approach," Mod. Lang. J., vol. 82, no. 2, p. 286, 2004.

[20] Piyaporn Punkasirikul, "Multimodal Critical Discourse Analysis: Basic Concepts, Approaches, Applications, and Reflections on Analyzing Thai Language Texts," $K K U$ Int. J. Humanit. Soc. Sci., vol. 8, no. 1, 2018.

[21] Suherman, "Sistem Appraisal Berita Kriminal pada Harian Meteor dan Harian Suara Merdeka,” Universitas Diponegoro, 2008.

[22] P. R. R. White, "Telling Media Tales : the news story as rhetoric," University of Sydney, 1998.

[23] A.J. Harahap, E. Ongko, H. Manurung, D. Kurnia, H. Hartono, D. Abdullah, K. Saddhono, and C.I Erliana "Sylabus and Matrials Design for Vocational Student and Its Dissemination Using Website." In IOP Journal of Physics: Conference Series, vol. 1114 no. 1, p. 012023. IOP Publishing, 2018. 